\title{
HSD3B1 wt Allele
}

National Cancer Institute

\section{Source}

National Cancer Institute. HSD3B1 wt Allele. NCI Thesaurus. Code C114368.

Human HSD3B1 wild-type allele is located in the vicinity of $1 \mathrm{p} 13.1$ and is approximately 8 $\mathrm{kb}$ in length. This allele, which encodes 3 beta-hydroxysteroid dehydrogenase/delta 5->4isomerase type 1 protein, is involved in both oxidative conversion of ketosteroids and the biosynthesis of hormonal steroids. 